\title{
PENGEMBANGAN STRATEGI UNTUK MENGELOLA RISIKO PADA INDUSTRI BIODIESEL DENGAN PENDEKATAN SISTEM INTELEJEN LOGIKA FUZZY
}

\author{
Anggara Hayun Anujuprana \\ Program Studi Teknik Industri, Universitas Bina Nusantara, Jakarta \\ E-mail: hayun_its@yahoo.co.uk
}

\begin{abstract}
ABSTRAK
Industri biodiesel merupakan salah satu industri yang menjadi alternatif pemerintah untuk mengatasi masalah krisis energi di Indonesia. Namun, pada kenyataannya, dari 62 perusahaan biodiesel yang ada sejak awal pengembangan industri biodiesel di Indonesia, pada saat ini hanya 2 perusahaan biodiesel yang masih berproduksi. Penelitian ini bertujuan membuat sistem cerdas untuk mengelola risiko industri biodiesel dengan pendekatan fuzzy AHP dan fuzzy inference system sehingga diperoleh strategi pengelolaan risiko industri biodiesel yang akurat. Metode analisis dalam penelitian ini adalah pendekatan sistem, fuzzy AHP, dan fuzzy inference system. Hasil penelitian diperoleh strategi pengendalian risiko merupakan strategi pengelolaan risiko yang terbaik di industri biodiesel. Implementasi dengan menggunakan fuzzy inference system menunjukkan bahwa keakuratan biodiesel terjual sebesar $80 \%$.
\end{abstract}

Kata Kunci: Manajemen Risiko, Strategi, Pendekatan Sistem, Fuzzy AHP, Dan Fuzzy Inference System

\begin{abstract}
Biodiesel industry is one industry which is the government alternative to overcome energy crisis in Indonesia. However, in reality, from 62 biodiesel companies that have since the beginning of the development of biodiesel industry in Indonesia, at the moment only 2 companies that are still to produce biodiesel. This study aims to create intelligent systems for managing risk biodiesel industry with the fuzzy AHP approach and fuzzy inference system so that risk management strategies in biodiesel industry is accurate. Methods of analysis in this research is the approach system, fuzzy AHP, and fuzzy inference system. Results obtained by the risk control strategy is the best risk management strategy in the biodiesel industry. Implementation using the fuzzy inference system shows that the accuracy of biodiesel sold output of $80 \%$.
\end{abstract}

Keywords: Risk Management, Strategy, System Methodology, Fuzzy AHP, Dan Fuzzy Inference System

\section{PENDAHULUAN}

Produksi Bahan Bakar Minyak (BBM) Indonesia dari tahun ke tahun mengalami trend penurunan. Pada tahun 2000, produksi BBM Indonesia sebanyak 1,4 juta barel perhari. Pada tahun 2001, 2002, 2003, sampai dengan 2007 produksi BBM Indonesia menjadi 1,3; 1,2; 1,1; sampai dengan 0,954 juta barel perhari. Di sisi lain, konsumsi BBM dari tahun ke tahun semakin meningkat. Indonesia yang saat ini dikenal sebagai salah satu negara pengekspor minyak bumi, diperkirakan akan mengimpor pada 10 tahun mendatang karena produksi minyak dalam negeri tidak dapat memenuhi permintaan pasar yang meningkat dengan cepat akibat pertumbuhan penduduk dan industri. [1]

Dari 62 perusahaan biodiesel yang ada sejak awal pengembangan industri biodiesel di Indonesia, pada saat ini hanya 2 perusahaan biodiesel yang masih berproduksi Hal ini disebabkan industri biodiesel merupakan industri baru (infant industry) yang memiliki risiko tinggi. Saat harga minyak tinggi, bisnis biodiesel menarik. Tetapi, apabila harga minyak dunia sudah kembali ke kisaran $\$ 50$ perbarel, bisnis biodiesel menjadi kurang menguntungkan. Orang cenderung memilih solar yang memiliki harga lebih murah. [2] 
Beberapa penelitian mengenai pengelolaan risiko diantaranya adalah analisis risiko pada kasus epidemi penyakit pada gandum, efek penyakit dan biaya yang ditimbulkan dalam perusahaan ternak perah [3], evaluasi dan adaptasi teknologi baru dalam sistem pertanian yang mengandung tingkat risiko tinggi. Schmuker mengembangkan metode fuzzy risk analysis dengan perangkat analisis risiko yang dapat membantu mengatasi masalah kompleksitas dan ketidaktepatan yang melekat. Aplikasi dalam penelitian awal menunjukkan terjadinya peningkatan keakuratan hasil analisis risiko sebesar $20 \%$ pada studi kasus risiko lingkungan. [4]

Berdasarkan hal tersebut diatas, maka perlu adanya kajian mengenai strategi pengelolaan risiko di industri biodiesel. Kajian menggunakan metode fuzzy AHP untuk menentukan strategi pengelolaan risiko dan fuzzy inference system untuk mengimplementasi strategi yang diperoleh. Dengan adanya strategi pengelolaan risiko yang tepat, diharapkan industri biodiesel dapat berkembang dengan baik.

\section{Agroindustri Biodiesel}

\section{TINJAUAN PUSTAKA}

Agroindustri adalah industri yang mengolah bahan baku hasil pertanian yang merupakan tanaman atau hewan dengan proses transformasi dan pengawetan secara fisik atau kimiawi, penyimpanan, pengemasan, dan distribusi. Berdasarkan definisi tersebut, maka dapat didefinisikan agroindustri biodiesel adalah industri yang mengolah bahan baku hasil pertanian seperti kelapa sawit, kelapa, dan jarak pagar untuk diolah menjadi produk biodiesel.

Adanya dukungan kebijakan pemerintah seperti UU No 30 tahun 2007 tentang energi, Inpres No 1 tahun 2006 tentang penyediaan dan pemanfaatan bahan bakar nabati sebagai bahan bakar lain, Peraturan Presiden No 5 tahun 2006 tentang kebijakan energi nasional, dan kebijakan-kebijakan lainnya diharapkan dapat menciptakan pasar untuk industri biodiesel dan insentif bagi pengembangan industri biodiesel di Indonesia.

Pasar industri biodiesel diciptakan melalui target energy mix 2025 yang ingin dicapai oleh Indonesia sebesar 5\% pemakaian solar di Indonesia. Target tersebut berarti pasar industri biodiesel Indonesia pada tahun 2025 diperkirakan mencapai 10,22 juta kilo liter.

\section{Konsep Risiko}

Risiko adalah ketidakpastian tentang kejadian di masa depan. Risiko dapat juga didefinisikan sebagai kejadian yang merugikan. Definisi lain dari risiko yang sering dipakai untuk analisis investasi adalah kemungkinan hasil yang diperoleh menyimpang dari yang diharapkan [5]. Dari beberapa definisi tersebut, maka risiko dihubungkan dengan kemungkinan terjadinya akibat buruk (kerugian) yang tak diinginkan atau tidak terduga. Dengan kata lain, kemungkinan itu sudah menunjukkan adanya ketidakpastian. Ketidakpastian merupakan kondisi yang menyebabkan tumbuhnya risiko. Ketidakpastian memiliki banyak tingkatannya. Tabel 1 menunjukkan tingkatan ketidakpastian dengan karakteristiknya.

Jika risiko menimpa suatu organisasi, maka organisasi tersebut dapat mengalami kerugian yang signifikan. Oleh karena itu, risiko penting untuk dikelola. Manajemen risiko bertujuan untuk mengelola risiko sehingga organisasi dapat mengoptimalkan risiko. Manajemen risiko pada dasarnya dilakukan melalui proses identifikasi risiko, evaluasi dan pengukuran risiko, dan pengelolaan risiko. 


\section{Kerangka Pemikiran}

\section{METODE PENELITIAN}

Penelitian ini dilakukan dengan menggunakan pendekatan sistem. Penelitian dimulai dengan analisa kebutuhan industri biodiesel terhadap pengelolaan risiko. Dalam analisa kebutuhan, dilakukan identifikasi sistem. Hasil analisis kebutuhan dan identifikasi sistem adalah perumusan masalah dan tujuan pengelolaan risiko industri biodiesel. Setelah merumuskan masalah dan tujuan, langkah selanjutnya adalah mengidentifikasi risiko. Kemudian ditentukan kriteria dan alternatif pengelolaan risiko serta penyusunan hirarki. Setelah hirarki tersusun, dilakukan pengolahan dengan menggunakan fuzzy AHP. Hasil pengolahan dengan fuzzy AHP diperoleh strategi pengelolaan risiko. Tahap terakhir penelitian adalah implementasi strategi dengan menggunakan fuzzy inference system. Kerangka pemikiran secara lengkap dapat dilihat pada Gambar 1.

\section{Pengumpulan Data}

Data yang dikumpulkan penelitian ini terdiri dari data primer dan data sekunder. Data primer diperoleh dari wawancara dan pengisian kuesioner oleh ahli di bidang industri biodiesel. Dalam proses akuisisi pengetahuan, penetapan responden yaitu ahli didasarkan pada pertimbangan: keberadaan responden, keterjangkauan, dan kesediaan untuk diwawancarai, mempunyai reputasi, kedudukan, dan telah menunjukkan kredibilitasnya sebagai ahli, serta telah berpengalaman dibidangnya. Berdasarkan kriteria responden yang dipilih untuk memperoleh data primer ada 3 orang yaitu peneliti, dosen, dan perwakilan perusahaan biodiesel. Sedangkan data sekunder diperoleh dari buku tentang biodiesel, jurnal, laporan penelitian biodiesel, dan internet.

\section{Pengolahan Data}

Pengolahan data dilakukan dengan menggunakan pendekatan sistem, fuzzy AHP dan fuzzy inference system. Pengolahan data dengan pendekatan sistem untuk memperoleh kebutuhan dan identifikasi sistem. Pengolahan data dengan menggunakan fuzzy AHP untuk memperoleh strategi pengelolaan risiko industri biodiesel. Tahapan pengolahan data dengan fuzzy AHP terdiri dari penyusunan hirarki, pembobotan kriteria dan alternatif dengan fuzzy, penentuan konsistensi, dan pemilihan strategi pengelolaan risiko. Sedangkan pengolahan data dengan menggunakan fuzzy inference system untuk mengimplementasi strategi yang telah diperoleh. Tahapan pengolahan data dengan fuzzy inference system terdiri dari akuisisi dan representasi pengetahuan ahli, pengembangan rule fuzzy inference system, implementasi fuzzy inference system, dan pengujian sistem.

\section{Perancangan Baris Aturan Fuzzy}

Perancangan baris aturan fuzzy dilakukan melalui wawancara dengan pakar. Pakar memberikan pendapat input yang diperlukan untuk membangun sistem cerdas.Input-input tersebut kemudian ditentukan nilai linguisticnya. Input dengan nilai linguistic masingmasing kemudian dikaitkan satu sama lain dengan menghasilkan output dengan nilai linguistic tertentu.

\section{Analisis Kebutuhan}

Analisis kebutuhan menggambarkan kebutuhan masing-masing pelaku terhadap keberadaan industri biodiesel. Kebutuhan masing-masing pelaku saling terkait satu sama lain sehingga dapat mempengaruhi pengelolaan risiko di industri biodiesel. Analisis kebutuhan dapat dilihat pada Tabel 1. 


\section{Identifikasi Sistem}

Pengelolaan risiko industri biodiesel harus dilandasi dengan pola pikir sistem yang mengkaitkan kebutuhan masing-masing pihak dalam industri biodiesel. Output yang dikehendaki adalah pemenuhan kebutuhan hasil identifikasi kebutuhan pada masingmasing pelaku. Sedangkan output yang tidak dikehendaki adalah dampak dari pengembangan model pengelolaan risiko industri biodiesel. Apabila output yang tidak dikehendaki terjadi, maka perlu dilakukan peninjauan kembali kontrol manajemen terhadap input yang dapat dikendalikan.

\section{Perumusan Masalah}

Permasalahan yang dihadapi pelaku industri biodiesel yang berkaitan dengan manajemen risiko adalah:

- Bahan baku biodiesel belum tersedia dalam jumlah, kualitas, harga, dan kontinuitas yang diperlukan

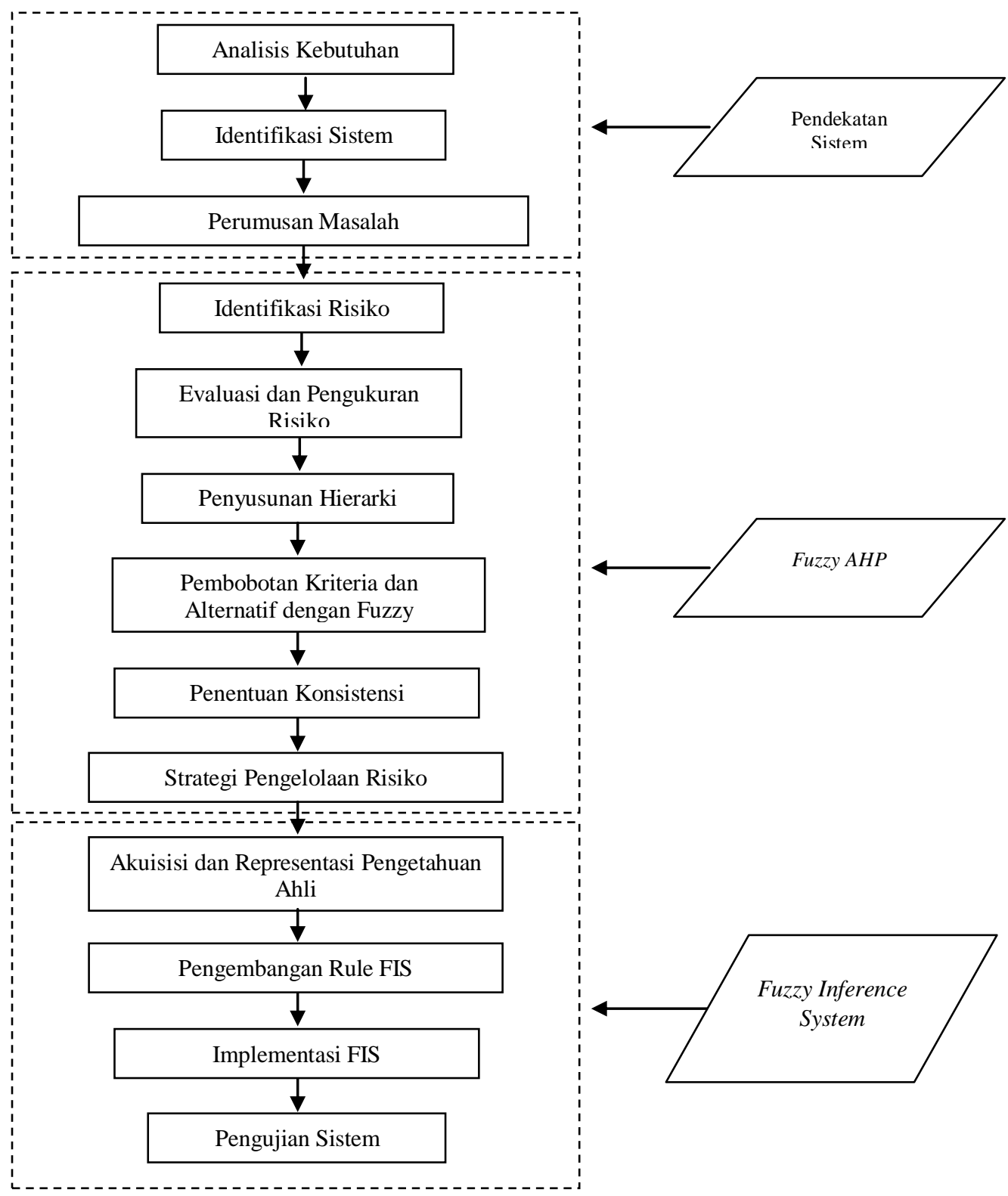

Gambar 1 Kerangka Pemikiran Strategi Pengelolaan Risiko Industri Biodiesel 


\section{HASIL DAN PEMBAHASAN}

Bahan baku yang tersedia pada saat ini (CPO) merupakan bahan baku untuk industri pangan dan industri lainnya, sehingga apabila digunakan untuk bahan baku biodiesel dapat mengganggu bahan baku industri pangan dan industri lainnya.

- BBM di Indonesia pada saat ini disubsidi sehingga harga jual biodiesel kurang kompetitif dibandingkan dengan harga jual BBM.

Tabel 1 Analisis Kebutuhan Pelaku terhadap Pengelolaan Risiko di Industri Biodiesel

\begin{tabular}{|c|c|c|}
\hline No & Pelaku & Kebutuhan \\
\hline 1 & Petani & $\begin{array}{l}\text { 1. Harga jual komoditas yang layak, tidak fluktuatif, dan adanya } \\
\text { jaminan pemasaran yang saling menguntungkan } \\
\text { 2. Tersedianya teknologi budidaya dan sarana produksi yang } \\
\text { terjangkau } \\
\text { 3. Peningkatan pendapatan dan kesejahteraan } \\
\text { 4. Kemudahan memperoleh informasi dan akses pasar yang lebih } \\
\text { luas } \\
\text { 5. Kemudahan dalam akses dan persyaratan dalam mengajukan } \\
\text { kredit ke lembaga keuangan }\end{array}$ \\
\hline 2 & Industri biodiesel & $\begin{array}{l}\text { 1. Tersedianya bahan baku yang kontinu dalam jumlah dan kualitas } \\
\text { yang sesuai dengan yang dipersyaratkan } \\
\text { 2. Adanya kesepakatan harga bahan baku yang saling } \\
\text { menguntungkan } \\
\text { 3. Adanya saling pengertian dan kerjasama yang harmonis antara } \\
\text { petani dan industri biodiesel } \\
\text { 4. Adanya teknologi pengolahan yang dapat menghasilkan produk } \\
\text { biodiesel berkualitas secara efektif dan efisien } \\
\text { 5. Kepastian pasar (transportasi, industry, PLN, atau swasta) }\end{array}$ \\
\hline 3 & Pertamina & $\begin{array}{l}\text { 1. Kelancaran pasokan biodiesel } \\
\text { 2. Kualitas biodiesel terjamin } \\
\text { 3. Harga biodiesel stabil }\end{array}$ \\
\hline 4 & SPBU & $\begin{array}{l}\text { 1. Kelancaran pasokan biodiesel } \\
\text { 2. Kualitas biodiesel terjamin }\end{array}$ \\
\hline 5 & Pemerintah & $\begin{array}{l}\text { 1. Meningkatkan ketahanan energi } \\
\text { 2. Meningkatkan pajak pendapatan } \\
\text { 3. Meningkatkan daya saing produk } \\
\text { 4. Harga biodiesel stabil }\end{array}$ \\
\hline 6 & Lembaga keuangan & $\begin{array}{l}\text { 1. Pengembalian kredit lancar } \\
\text { 2. Risiko kegagalan usaha rendah } \\
\text { 3. Terjaminnya modal/investasi yang ditanam }\end{array}$ \\
\hline 7 & Masyarakat & $\begin{array}{l}\text { 1. Terciptanya lapangan kerja baru } \\
\text { 2. Meningkatnya pendapatan dan kesejahteraan masyarakat sekitar } \\
\text { 3. Minimnya risiko limbah industri biodiesel yang ditimbulkan } \\
\text { 4. Bahan bakar ramah lingkungan }\end{array}$ \\
\hline 8 & Industri & Bahan bakar untuk pembangkit listrik, generator atau boiler \\
\hline
\end{tabular}

\section{Identifikasi Risiko}

Berdasarkan hasil diskusi dengan pakar, risiko pada industri biodiesel adalah: kontinuitas bahan baku (jumlah dan kualitas), fluktuasi harga BBM dan harga komoditas pertanian bahan baku biodiesel, subsidi BBM, kepastian pasar, dampak sosial, dampak negatif ekologis, dampak positif ekologis. 


\section{Evaluasi dan Pengukuran Risiko}

Hasil identifikasi risiko kemudian dilakukan evaluasi dan pengukuran dengan menggunakan matriks frekuensi dan dampak. Berdasarkan Gambar 2 terlihat bahwa risiko industri biodiesel terletak pada kuadran I, II, dan III.

\section{Penyusunan Hierarki}

Penyusunan hierarki dilakukan melalui wawancara mendalam dengan beberapa pakar yang menghasilkan susunan hierarki strategi pengelolaan risiko industri biodiesel dengan 3 level yaitu fokus/goal, tujuan, dan alternatif strategi.

- Level 2 yaitu tujuan.

Tujuannya adalah:

a. Menanggulangi risiko kontinuitas bahan baku

b. Menanggulangi risiko fluktuasi harga BBM dan harga komoditas pertanian bahan baku biodiesel

c. Menanggulangi risiko kepastian pasar

d. Menanggulangi risiko subsidi BBM

e. Menanggulangi risiko dampak sosial

f. Menanggulangi risiko dampak negatif ekologis

g. Menanggulangi risiko dampak positif ekologis

- Level 3 yaitu alternatif strategi.

Alternatif strategi pengelolaan risiko industri biodiesel adalah:

a. Penahanan risiko (retention risk)

b. Diversifikasi risiko

c. Transfer risiko

d. Pengendalian risiko

\section{Penilaian Pakar dengan Menggunakan Fuzzy AHP}

Berdasarkan penyusunan hierarki, terdapat 8 matriks yang akan dibuat kuesioner dan diisi oleh pakar sebagai

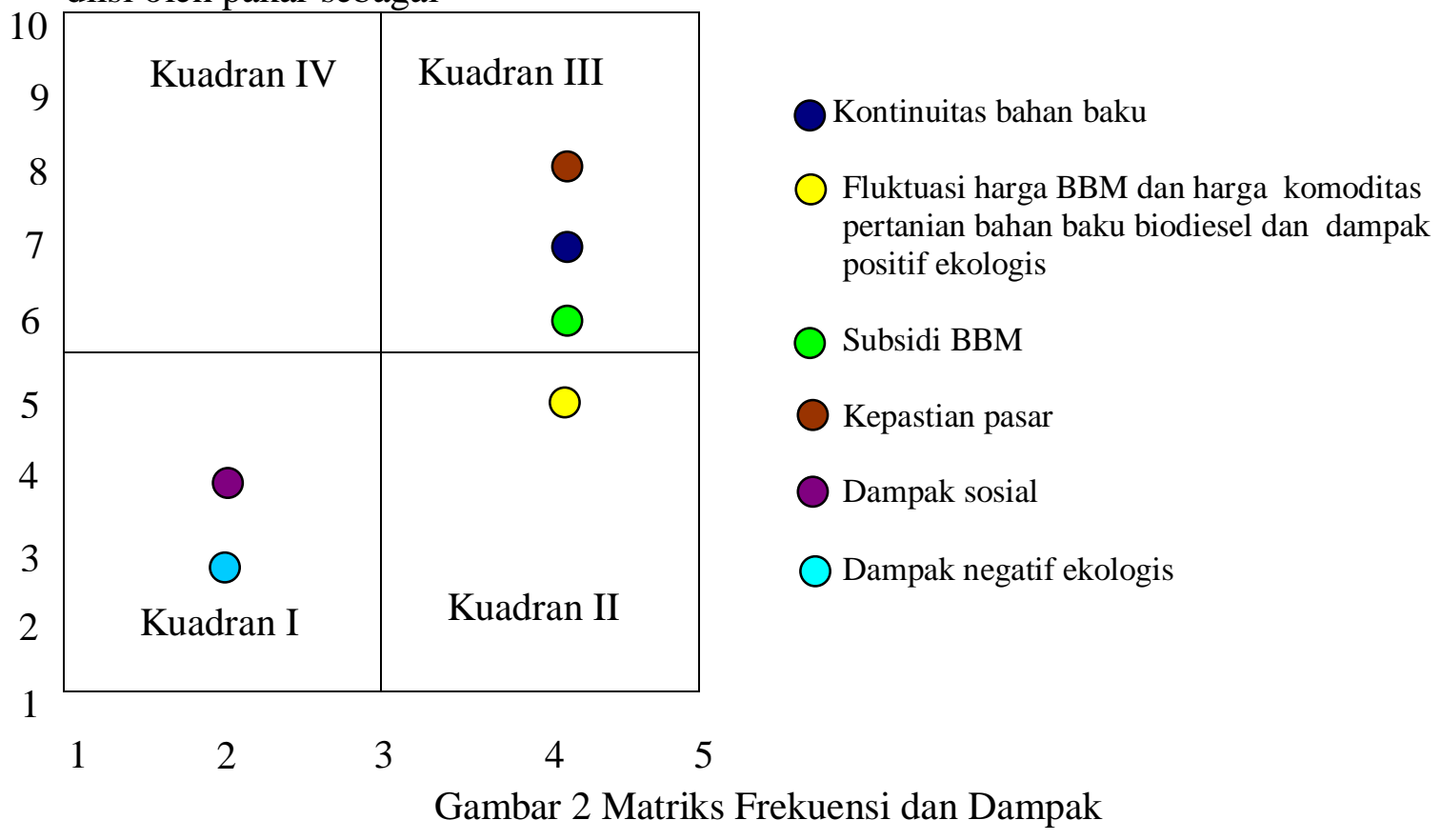


Hasil pengisian pakar kemudian diagregasi dan difuzzyfikasi berdasarkan aturan TFN (Trianguler Fuzzy Number). Contoh hasil agregasi dan defuzzyfikasi dapat dilihat pada Tabel 2.

Tabel 2 Hasil Agregasi dan Fuzzyfikasi Matriks Antar Tujuan (M1)

\begin{tabular}{lcccr}
\hline \multicolumn{1}{c}{ Dari Tujuan } & BB & BT & BA & Menuju Tujuan \\
\hline Kontinuitas Bahan Baku & 1,000 & 3,000 & 5,000 & Fluktuasi Harga \\
Kontinuitas Bahan Baku & 0,447 & 1,000 & 2,236 & Kepastian Pasar \\
Kontinuitas Bahan Baku & 0,655 & 1,000 & 1,528 & Subsidi BBM \\
Kontinuitas Bahan Baku & 1,732 & 3,873 & 5,916 & Dampak Sosial \\
Kontinuitas Bahan Baku & 1,000 & 1,528 & 3,000 & Dampak Negatif Ekologis \\
Kontinuitas Bahan Baku & 1,000 & 1,528 & 3,000 & Dampak Positif Ekologis \\
Fluktuasi Harga & 0,258 & 0,577 & 1,732 & Kepastian Pasar \\
Fluktuasi Harga & 0,200 & 0,333 & 1,000 & Subsidi BBM \\
Fluktuasi Harga & 1,000 & 3,000 & 5,000 & Dampak Sosial \\
Fluktuasi Harga & 0,447 & 1,000 & 2,236 & Dampak Negatif Ekologis \\
Fluktuasi Harga & 0,447 & 1,000 & 2,236 & Dampak Positif Ekologis \\
Kepastian Pasar & 0,447 & 1,000 & 2,236 & Subsidi BBM \\
Kepastian Pasar & 1,000 & 2,236 & 4,583 & Dampak Sosial \\
Kepastian Pasar & 1,000 & 1,528 & 3,000 & Dampak Negatif Ekologis \\
Kepastian Pasar & 1,000 & 1,528 & 3,000 & Dampak Positif Ekologis \\
Subsidi BBM & 1,000 & 3,000 & 5,000 & Dampak Sosial \\
Subsidi BBM & 1,000 & 3,000 & 5,000 & Dampak Negatif Ekologis \\
Subsidi BBM & 1,000 & 3,000 & 5,000 & Dampak Positif Ekologis \\
Dampak Sosial & 0,333 & 0,655 & 1,000 & Dampak Negatif Ekologis \\
Dampak Sosial & 0,378 & 0,775 & 1,291 & Dampak Positif Ekologis \\
Dampak Negatif Ekologis & 0,333 & 1,000 & 3,000 & Dampak Positif Ekologis \\
\hline
\end{tabular}

\section{Defuzzifikasi}

Proses defuzzifikasi diperlukan untuk memperoleh hasil tunggal dari proses fuzzyfikasi. Defuzzifikasi dilakukan dengan menggunakan metode mean geometric. Contoh hasil defuzzifikasi adalah sebagai berikut:Defuzzifikasi M1

$\left(\begin{array}{lllllll}1,000 & 2,466 & 1,000 & 1,000 & 3,411 & 1,661 & 1,661 \\ 0,405 & 1,000 & 0,637 & 0,405 & 2,466 & 1,000 & 1,000 \\ 1,000 & 1,570 & 1,000 & 1,000 & 2,172 & 1,661 & 1,661 \\ 1,000 & 2,466 & 1,000 & 1,000 & 2,466 & 2,466 & 2,466 \\ 0,293 & 0,405 & 0,460 & 0,405 & 1,000 & 0,602 & 0,723 \\ 0,602 & 1,000 & 0,602 & 0,405 & 1,661 & 1,000 & 1,000 \\ 0,602 & 1,000 & 0,602 & 0,405 & 1,383 & 1,000 & 1,000\end{array}\right)$

\section{Pembobotan Tujuan dan Alternatif}

Pembobotan tujuan dan alternatif dilakukan dengan mengkuadratkan masing-masing matriks defuzzifikasi. Hasil pengkuadratan matriks dicari jumlah baris dan hasil normalisasinya. Setelah itu, hasil pengkuadratan matriks dikuadratkan kembali dan dicari jumlah baris dan hasil normalisasinya kembali. Demikian seterusnya langkah tersebut dilakukan sampai dengan perbedaan nilai eigen sebelum dan sesudahnya tidak terlalu besar sampai dengan 4 desimal. 
Tabel 3 Hasil Pembobotan Tujuan dan Alternatif

\begin{tabular}{lccccccccc}
\hline & Tujuan 1 & Tujuan 2 & Tujuan 3 & Tujuan 4 & Tujuan 5 & Tujuan 6 & Tujuan 7 & Hasil & Peringkat \\
\hline Alt Strategi 1 & 0,15 & 0,10 & 0,11 & 0,10 & 0,25 & 0,14 & 0,22 & 0,14 & 4 \\
Alt Strategi 2 & 0,38 & 0,28 & 0,12 & 0,31 & 0,12 & 0,44 & 0,23 & 0,28 & 2 \\
Alt Strategi 3 & 0,15 & 0,55 & 0,13 & 0,29 & 0,13 & 0,22 & 0,25 & 0,24 & 3 \\
Alt Strategi 4 & 0,32 & 0,07 & 0,64 & 0,31 & 0,50 & 0,20 & 0,16 & 0,33 & 1 \\
Bobot Tujuan & 0,21 & 0,11 & 0,18 & 0,22 & 0,07 & 0,11 & 0,10 & & \\
\hline
\end{tabular}

Dari Tabel 3 terlihat bahwa alternatif strategi 4 yaitu pengendalian risiko memiliki bobot yang tertinggi $(0,33)$. Secara berurutan alternatif strategi 2 yaitu diversifikasi risiko, alternatif strategi 3 yaitu transfer risiko, dan alternatif strategi 1 yaitu penahanan risiko menduduki peringkat 2, 3, dan 4 dengan bobot 0,$28 ; 0,24$; dan 0,14 . Hal ini berarti strategi terpilih untuk pengelolaan risiko industri biodiesel adalah strategi pengendalian risiko. Strategi pengendalian risiko dapat diartikan bahwa industri biodiesel harus mencegah atau menurunkan probabilitas terjadinya risiko atau kejadian yang tidak diinginkan.

\section{Penentuan Konsistensi}

Konsistensi pengisian kuesioner oleh pakar dapat terlihat dari nilai consistency ratio (CR). Apabila nilai CR lebih kecil atau sama dengan 0,1 maka pengisian kuesioner dikatakan konsisten. Tetapi, apabila nilai CR lebih besar daripada 0,1 berarti pengisian kuesioner tidak konsisten. Hasil penilaian CR dapat dilihat pada Tabel 4.

Tabel 4 Hasil Penilaian CR

\begin{tabular}{lcccccccc}
\hline & Matriks 1 & Matriks 2 & Matriks 3 & Matriks 4 & Matriks 5 & Matriks 6 & Matriks 7 & Matriks 8 \\
\hline $\begin{array}{c}\text { Consistency } \\
\text { Ratio (CR) }\end{array}$ & 0,046 & 0,021 & 0,018 & 0,007 & 0,003 & 0,011 & 0,008 & 0,008 \\
Keputusan & Konsisten & Konsisten & Konsisten & Konsisten & Konsisten & Konsisten & Konsisten & Konsisten \\
\hline
\end{tabular}

Dari Tabel 4 terlihat bahwa semua matriks memiliki nilai CR lebih kecil sama dengan 0,1 . Hal ini berarti pengisian kuesioner yang dilakukan oleh pakar sudah konsisten.

\section{Implementasi Strategi Pengelolaan Risiko dengan Fuzzy Inference System}

Berdasarkan hasil diskusi dengan pakar disepakati bahwa implementasi strategi pngelolaan risiko industri biodiesel yang terpilih yaitu strategi pengendalian risiko difokuskan pada kuadran III matriks risiko (lihat Gambar 3). Para pakar menyepakati bahwa implementasi strategi pengendalian risiko adalah inti plasma, efisiensi produksi, dan kampanye bahan bakar ramah lingkungan. Inti plasma untuk mengendalikan risiko kontinuitas bahan baku. Efisiensi produksi untuk mengendalikan risiko subsidi BBM. Sedangkan kampanye bahan bakar ramah lingkungan untuk mengendalikan risiko kepastian pasar. Hasil implementasi strategi pengendalian risiko adalah output berupa biodiesel terjual.

Input inti plasma, efisiensi produksi, dan kampanye bahan bakar ramah lingkungan diberikan nilai linguistic fuzzy: rendah, sedang, dan tinggi. Sedangkan output biodiesel terjual juga memiliki nilai linguistic fuzzy: rendah, sedang, dan tinggi. Setiap input mempunyai kemungkinan 3 nilai linguistic dan input sistem ada 3, sehingga diperlukan 27 rules untuk mengimplementasikan fuzzy inference system ini. Representasi fuzzy dari nilai linguistic dengan menggunakan Triangular Fuzzy Number (TFN). Secara lengkapnya rules pada stategi pengelolaan risiko industri biodiesel dapat dilihat pada Tabel 5. 


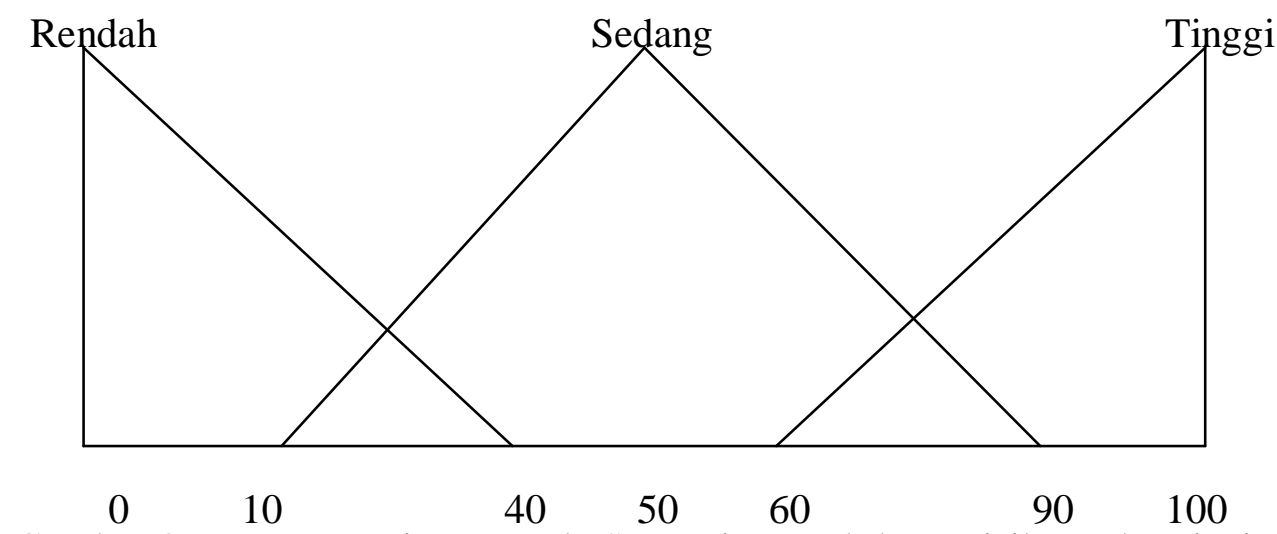

Gambar 3. Representasi TFN pada Strategi Pengelolaan Risiko Industri Biodiesel

\begin{tabular}{ccccc} 
Tabel 5 Penyusunan Rules Strategi Pengelolaan Risiko Industri Biodiesel \\
\cline { 2 - 5 } Rules & Inti Plasma & $\begin{array}{c}\text { Efisiensi } \\
\text { Produksi }\end{array}$ & Kampanye & $\begin{array}{c}\text { Biodiesel } \\
\text { Terjual }\end{array}$ \\
\hline 1 & Tinggi & Tinggi & Tinggi & Tinggi \\
2 & Tinggi & Tinggi & Sedang & Tinggi \\
3 & Tinggi & Tinggi & Rendah & Sedang \\
4 & Tinggi & Sedang & Tinggi & Tinggi \\
5 & Tinggi & Sedang & Sedang & Sedang \\
6 & Tinggi & Sedang & Rendah & Rendah \\
7 & Tinggi & Rendah & Tinggi & Sedang \\
8 & Tinggi & Rendah & Sedang & Sedang \\
9 & Tinggi & Rendah & Rendah & Rendah \\
10 & Sedang & Tinggi & Tinggi & Tinggi \\
11 & Sedang & Tinggi & Sedang & Sedang \\
12 & Sedang & Tinggi & Rendah & Sedang \\
13 & Sedang & Sedang & Tinggi & Sedang \\
14 & Sedang & Sedang & Sedang & Sedang \\
15 & Sedang & Sedang & Rendah & Sedang \\
16 & Sedang & Rendah & Tinggi & Sedang \\
17 & Sedang & Rendah & Sedang & Rendah \\
18 & Sedang & Rendah & Rendah & Rendah \\
19 & Rendah & Tinggi & Tinggi & Sedang \\
20 & Rendah & Tinggi & Sedang & Sedang \\
21 & Rendah & Tinggi & Rendah & Sedang \\
22 & Rendah & Sedang & Tinggi & Sedang \\
23 & Rendah & Sedang & Sedang & Sedang \\
24 & Rendah & Sedang & Rendah & Rendah \\
25 & Rendah & Rendah & Tinggi & Rendah \\
26 & Rendah & Rendah & Sedang & Rendah \\
27 & Rendah & Rendah & Rendah & Rendah \\
\hline & & & &
\end{tabular}

\section{Implementasi Fuzzy Inference System dengan Matlab}

Implementasi fuzzy inference system menggunakan software matlab 7.5.0. Metode yang digunakan untuk implementasi pada input maupun output adalah TFN. Operasi AND menggunakan fungsi min, operasi OR menggunakan fungsi max, operasi implikasi menggunakan fungsi product, agregasi menggunakan fungsi sum, dan defuzzyfikasi menggunakan fungsi centroid.

\section{Pengujian Sistem}

Pengujian sistem dilakukan melalui pengecekan akurasi fuzzy inference system. Pengecekan akurasi fuzzy inference system perlu dilakukan untuk mengetahui apakah rules yang telah dibuat sudah akurat atau belum. Cara mengecek akurasi fuzzy inference system dengan melakukan simulasi 
beberapa nilai inti plasma, efisiensi produksi, dan kampanye bahan bakar ramah lingkungan, kemudian dilihat apakah output biodiesel terjualnya sudah sesuai dengan yang terdapat pada membership fuction atau tidak. Hasil simulasi dicari prosentase biodiesel terjual benar atau tidak. Semakin tinggi tingkat prosentase kebenarannya maka semakin akurat rulesnya.

Hasil akurasi adalah $80 \%$. Hal ini berarti pengembangan rules dapat dikatakan akurat. Semakin tinggi nilai akurasi, semakin tinggi keakuratan rules yang dikembangkan. Apabila pada rules yang terjadi kesalahan pada saat dilakukan pengecekan, yaitu inti plasma tinggi, efisiensi produksi tinggi, dan kampanye sedang, output biodiesel terjual semula tinggi diubah menjadi sedang, maka terjadi perubahan rule viewer fuzzy inference system seperti terlihat pada Gambar 5.

Secara sekilas Gambar 4 dan 5 tidak terlihat bedanya. Untuk dapat melihat perbedaannya, maka perlu dilakukan pengecekan akurasi fuzzy inference system melalui simulasi beberapa nilai inti plasma, efisiensi produksi, dan kampanye bahan bakar ramah lingkungan. Hasil pengecekan dapat dilihat pada Tabel 6 .

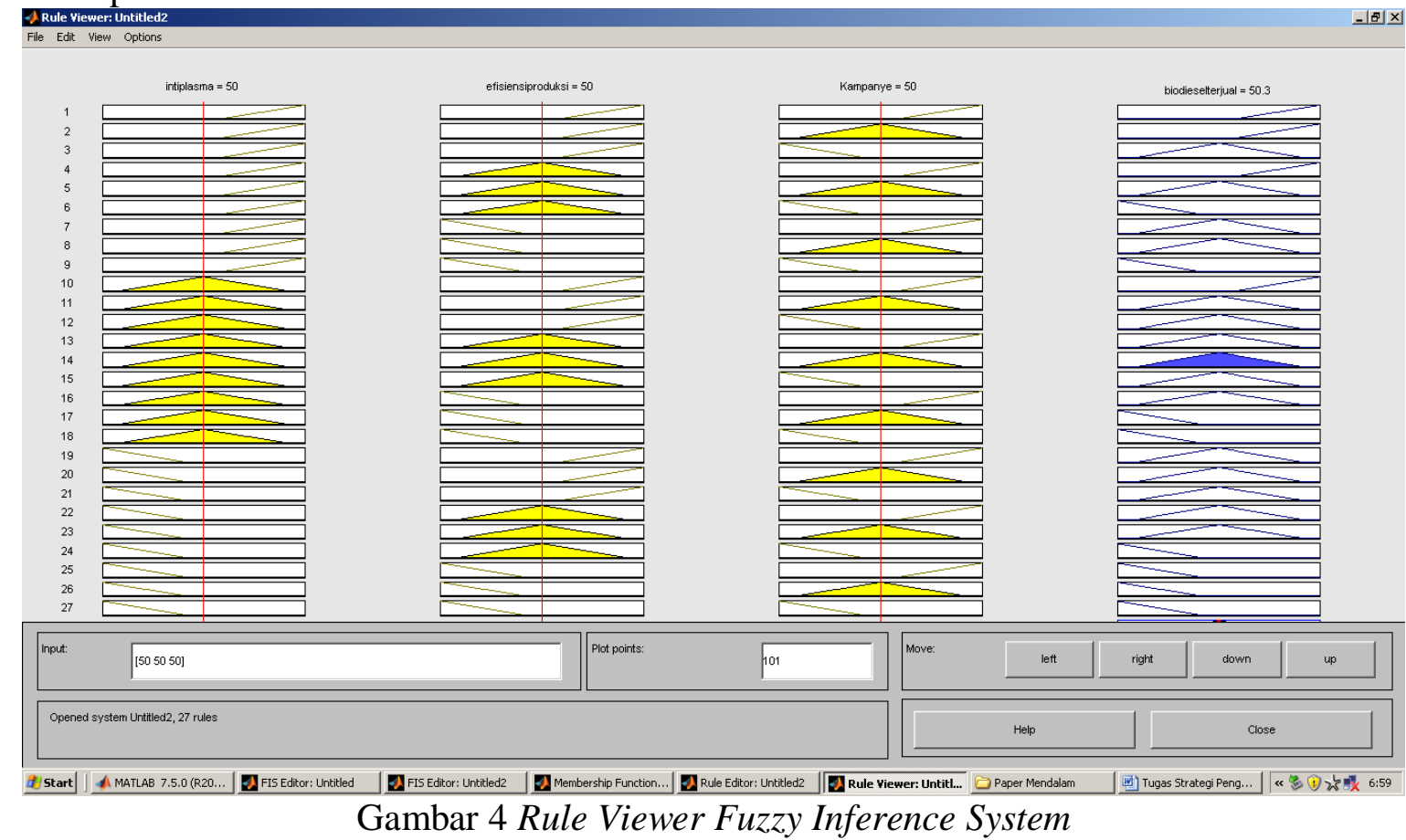

Tabel 6. Pengecekan Akurasi Fuzzy Inference System

\begin{tabular}{cccc}
\hline Inti Plasma & $\begin{array}{c}\text { Efisiensi } \\
\text { Produksi }\end{array}$ & Kampanye & $\begin{array}{c}\text { Biodiesel Terjual } \\
\text { (Benar/Salah) }\end{array}$ \\
\hline Tinggi & Tinggi & Tinggi & Tinggi (Benar) \\
Tinggi & Tinggi & Sedang & Tinggi (Salah) \\
Sedang & Tinggi & Rendah & Sedang (Benar) \\
Rendah & Sedang & Tinggi & Sedang (Benar) \\
Rendah & Sedang & Sedang & Sedang (Benar) \\
\hline
\end{tabular}




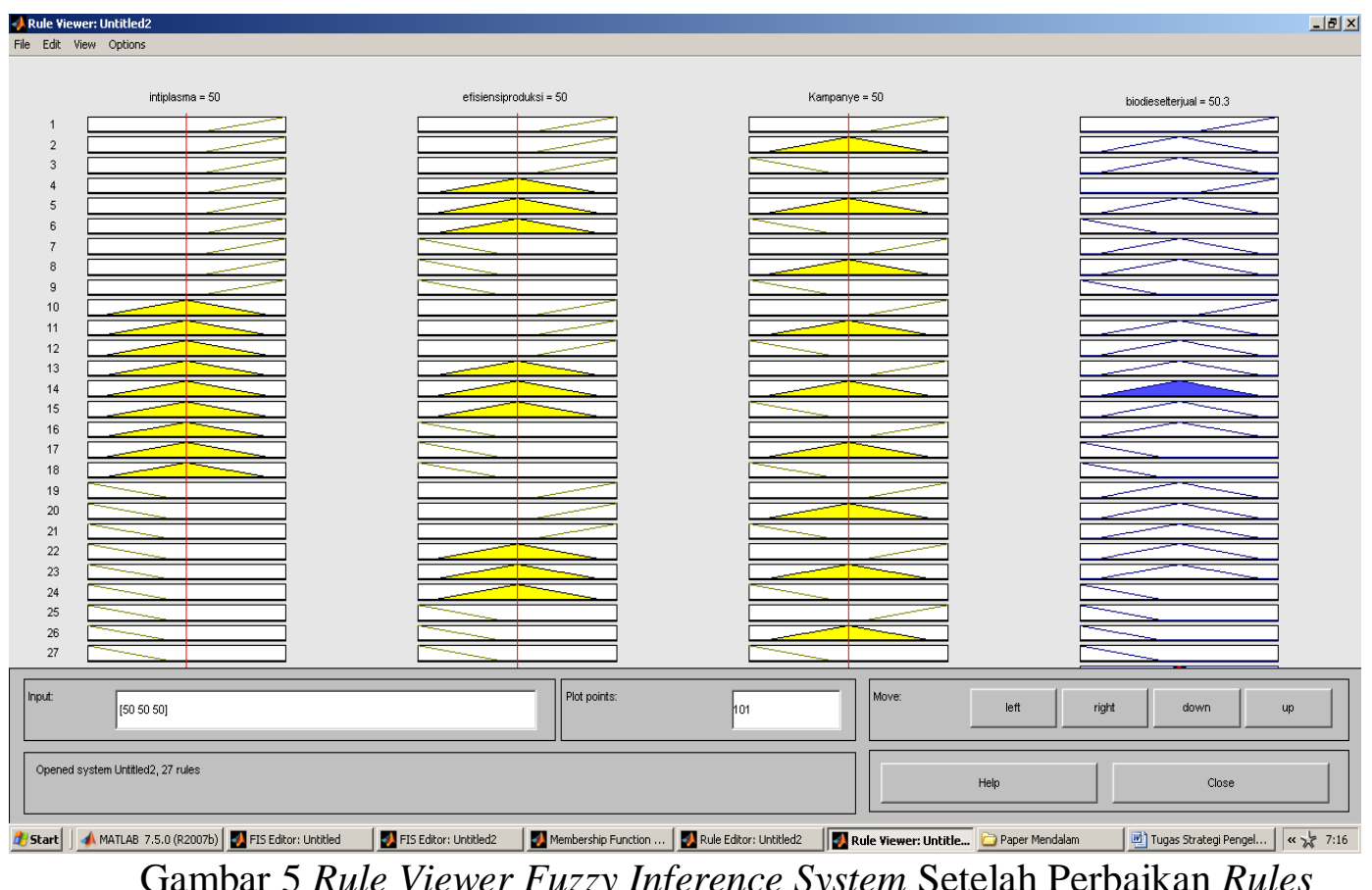

Gambar 5 Rule Viewer Fuzzy Inference System Setelah Perbaikan Rules

Tabel 7. Pengecekan Akurasi Fuzzy Inference System Setelah Perbaikan Rules

\begin{tabular}{cccc}
\hline $\begin{array}{c}\text { Inti } \\
\text { Plasma }\end{array}$ & $\begin{array}{c}\text { Efisiensi } \\
\text { Produksi }\end{array}$ & Kampanye & $\begin{array}{c}\text { Biodiesel Terjual } \\
\text { (Benar/Salah) }\end{array}$ \\
\hline Tinggi & Tinggi & Tinggi & Tinggi (Benar) \\
Tinggi & Tinggi & Sedang & Sedang (Benar) \\
Sedang & Tinggi & Rendah & Sedang (Benar) \\
Rendah & Sedang & Tinggi & Sedang (Benar) \\
Rendah & Sedang & Sedang & Sedang (Benar) \\
\hline
\end{tabular}

\section{KESIMPULAN}

Hasil identifikasi risiko diperoleh bahwa risiko pada industri biodiesel terdiri dari kontinuitas bahan baku (jumlah dan kualitas), fluktuasi harga BBM dan harga komoditas pertanian bahan baku biodiesel, subsidi BBM, kepastian pasar, dampak sosial, dampak negatif ekologis, dan dampak positif ekologis.

Hasil evaluasi dan pengukuran risiko diperoleh bahwa kontinuitas bahan baku, subsidi BBM, dan kepastian pasar terletak pada kuadran III. Hal ini berarti ketiga risiko tersebut perlu diperhatikan oleh industri biodiesel agar dapat mempertahankan kelangsungan hidupnya

Berdasarkan perhitungan dengan menggunakan fuzzy AHP, diperoleh hasil strategi pengendalian risiko menempati peringkat pertama dengan nilai 0,33 dan peringkat selanjutnya adalah strategi diversifikasi risiko dengan nilai 0,28. Hal ini berarti strategi yang terpilih adalah strategi pengendalian risiko.

Implementasi strategi pengendalian risiko industri biodiesel dengan membangun suatu sistem cerdas implementasi strategi terpilih untuk memperoleh output biodiesel terjual.

Nilai akurasi sistem cerdas implementasi strategi pengendalian risiko adalah $80 \%$. Hal ini berarti sistem yang dibuat akurat.

Apabila dilakukan perbaikan terhadap rules yang tidak akurat, nilai akurasi sistem cerdas akan meningkat. 


\section{DAFTAR PUSTAKA}

[1].Hendriadi A, Handaka, Lilik TM. 2005. Prospektif teknologi pengolahan biodiesel dari biji jarak (Crude Jatropha curcas Oil) skala pedesaan. Balai Besar Pengembangan Mekanisasi Pertanian.

[2].Hambali, Erliza, et. al.. 2008. Teknologi Bioenergi. PT AgroMedia Pustaka. Jakarta.

[3].Bennet, J. 1993. Genes for crop improvements. Genetic Enginnering

[4].Schmucker KJ. 1986. Fuzzy Sets, Natural Language Computations and Risk Analysis, Rockville: Computer Science Press, MD.

[5].Hanafi, M. Mamduh. 2006. Manajemen Risiko. UPP STIM YKPN. Yogyakarta.

[6].Eriyatno. 1998. Ilmu Sistem: Meningkatkan Mutu dan Efektivitas Manajemen. IPB Press. Bogor.

[7]. Hambali, Erliza, et. al. 2006. Jarak Pagar Tanaman Penghasil Biodiesel. Penebar Swadaya. Depok. Jawa Barat.

[8]. Marimin. 2007. Teori dan Aplikasi Sistem Pakar dalam Teknologi Manajerial. IPB Press. Cetakan II.

[9].Priyanto Unggul. 2007. Menghasilkan Biodiesel Jarak Pagar Berkualitas. PT AgroMedia Pustaka. Jakarta.

[10]. Radjab Rudy. 2008. Pemanfaatan Biofuel, Seminar Nasional Biofuel. DDESDM. Jakarta.

[11]. Roesyadi, A.. 2006. Aplikasi Minyak Jarak Sebagai Bahan Bakar Diesel. Teknik Kimia ITS. Surabaya.

[12]. Santoso, Imam. 2005. Rekayasa Model Manajemen Risiko untuk Pengembangan Agroindustri Buah-buahan secara Berkelanjutan. Disertasi. IPB. Bogor 